\title{
Robust Statistical Portfolio Investment in Modern Portfolio Theory: A Case Study of Two Stocks Combination in Kuala Lumpur Stock Exchange
}

\author{
Nashirah Abu Bakar, Sofian Rosbi
}

\begin{abstract}
Modern portfolio theory is a theory of diversification in portfolio selection to achieve lower risk for a target expected return. Therefore, the objective of this study is to reducing investment risk by developing diversification of portfolio investment using combination of two share prices that exhibits negative or low positive correlation. Data selected in this study are the rate of return for two companies that listed in Kuala Lumpur Stock Exchange (KLSE). The selected companies are Ajinomoto Malaysia Berhad and UMW Holdings Berhad. The methodologies involved in this project are expected return calculation, statistical normality checking, correlation diagnostics and expected variance evaluation for investment portfolio. The Pearson correlation analysis shows correlation value is -0.879. This finding concludes there is significant and strong negative correlation between share price return of UMW Holdings Berhad and Ajinomoto Malaysia Berhad. Result indicates the efficient frontier for investment is started with 42.5\% investment in Ajinomoto and 57.5\% investment in UMW. The expected portfolio return using this investment combination is 0.14 percentages. Meanwhile, the highest expected return on efficient frontier is 19.17 percentages. The investment combination for maximum return is $100 \%$ in Ajinomoto share price. The implication of this study is it will help investors to develop better decision about their portfolio investment with lower risk for a target of expected return.
\end{abstract}

Keywords: Investment, Modern Portfolio Theory, Correlation diagnostics, Efficient frontier.

\section{INTRODUCTION}

Investment decision is envisaged to be a complex process regarding unexpected rate of return and risk. Therefore, there are many studies focusing on the investment technique. The most famous technique implemented is Modern Portfolio Theory pioneer by Harry Markowitz in 1952. Modern Portfolio Theory explained how investors can optimal investment and consumption decisions of an individual who has available in two investment instruments (Markowitz, 1952)[1]. Therefore, this theory provides a framework to construct and select portfolios based on the expected performance of the investments and the risk appetite of the investor (Fabozzi, et al., 2002)[2].

Invests in many portfolios give advantages to investors in order to increase an expected rate of return by diversified their investment instruments either in differences countries

Revised Manuscript Received on April 19, 2019.

Nashirah Abu Bakar, Islamic Business School, College of Business, Universiti Utara Malaysia, 06010 Kedah, Malaysia.

Sofian Rosbi, School of Mechatronic Engineering, Universiti Malaysia Perlis, 02600 Arau, Malaysia. or differences market sectors. Diversification is a portfolio strategy that is designed to reduce the overall risk exposure by combining a variety of assets into one basket of portfolio (Abu Bakar and Rosbi, 2018)[3]. Study by Abu Bakar and Rosbi (2018)[4] regarding diversification diagnostic for portfolio investment using combination of cryptocurrency and stock price indicated that the portfolio risk can be reduced with the diversification approach for different assets. While Bahlous and Mohd Yusof (2014)[5] suggested that a global portfolio with stocks and bonds from different regions or countries should earn higher return for the same level of risk and carry less risk for the same level of return from a non-diversified portfolio. Bartkus and Kabir Hassan (2009)[6] investigates specialization versus diversification found that venture capitalists that diversify across portfolio company stage of development have greater success in bringing companies public and exiting their investments via acquisition. Therefore, diversification of the investment is one of the strategies that companies can choose in order to minimize unsystematic or firm-specific risk.

There are many studies focus on the diversification of investment using Modern Portfolio Theory, but it is still lack of researchers investigate the diversification of investment for companies listed on the Malaysian Stock Exchange. As mentioned by Securities Commission of Malaysia, the total number of companies listed on the Malaysian Stock Exchange is 901 companies (Securities Commission of Malaysia, 2018)[7]. Therefore, this study was investigated the performance of two companies listed on the Malaysian Stock Exchange using Modern Theory Portfolio.

\section{LITERATURE REVIEW}

Modern Portfolio Theory was developed by Harry Markowitz based on the approach that investors can construct portfolios investment to optimize or maximize expected return. Before Modern Portfolio Theory was developed, most of the investment are followed Theory of Investment that stated it was enough looking into only one stock (Kazan and Uludag, 2014)[8]. However, according to Modern Portfolio Theory, risk should not be ignored in investment and this theory was analyzing a stock under historical data in order to maximize a return and minimize a risk.

Published By: 
Modern Portfolio Theory also quantify the benefits of diversification and explore how risk-averse investors construct portfolios to optimize expected returns against market risks, linking both the expected return (or mean) of a portfolio diversification return and the variance of portfolio returns as the investment risk (Bin and Yuan, 2016)[9]. Abu Bakar and Rosbi (2018)[10] develop efficient frontier for portfolio investment consists of two stocks form Kuala Lumpur Stock Exchange (KLSE). The result shows expected portfolio return is 0.54 percentages at global minimum portfolio risk, 2.34 percentages. The findings of this study will help investors to select optimum investment weightage that minimize portfolio risk for a given amount of expected return. Malaysia Stock Exchange (MSE) was established in 1964. Since MSE was established, there are many researches are conducted to investigate the performance of companies listed on the Malaysia Stock Exchange (Zainudin, et al., 2018; Fauzi and Musallam, 2015; Ahmad-Zaluki, 2012; Lim, 2008)[11-14].

Zainudin, et al., (2018)[11] investigate he relationship between stock price volatility and dividend policy of industrial products firms listed on Bursa Malaysia. They found that earning volatility significantly explains stock price volatility of industrial product firms during the crisis period. Dividend payout ratio predominantly influences volatility during pre- and post-crisis sub-periods. The results also show that the dividend policy is a strong predictor of stock price volatility of industrial products firms in Malaysia, particularly during the post-crisis period.

Fauzi and Musallam (2015)[12] examine the effects of corporate ownership on company performance. They suggest that government-linked investment companies' ownership improves company performance, while board ownership destroys company performance. The results also show that while government-linked investment companies' ownership has an inverted U-shaped relationship with company performance, board ownership has a U-shaped relationship with company performance.

Lim (2008)[14] examine the relative efficiency of eight economic sectors in the Malaysian stock market and the impact of the 1997 Asian financial crisis. He found that the sector of tin and mining is found to be the most efficient sector. While, study regarding the extent of underpricing in the Saudi Arabian market of initial public offerings found that not only underpricing occurs but it is also among the highest levels in the world. The level of underpricing in the Saudi Arabian market is 266.72 per cent (initial return) being among the highest reported worldwide (Mayes and Alqahtani, 2015)[15].

Meanwhile, research regarding portfolio investment (Davis and Norman, 1990; Mansini and Speranza, 1999; Sing and Patel, 2001; Maurer and Valiani, 2007; Benjelloun et al., 2009; Nartea and Eves, 2010; Giannotti, et al., 2011; Chen and Pan, 2013; Lee and Stevenson, 2005; Puopolo, 2017; Champagne et al., 2018)[16-26] shows the variety of methods implement in their researches. Study from Azizan and Sorooshian (2014)[27] regarding the efficient frontier from modern portfolio theory in determine the best stocks performance in KLCI index conclude that the normal efficient portfolio which is the best performers after deduct the risk-free asset to its expected return.
Ou (2005)[28] developed a new theory of portfolio and risk based on incremental entropy and Markowitz's theory and found that the difference between the new theory based on incremental entropy and Markowitz's theory is the new theory emphasizes that there is an objectively optimal portfolio for given probability of returns.

Giannotti, et al. (2011)[29] evaluates the benefits related to a Markowitz diversification approach for the construction of a specialized portfolio in the hotel real estate market. They found that, standard geographic and sector diversification allow for good results, the more efficient portfolios are more concentrated. Lassoued and Elmir, (2012)[30] examine whether corporate governance has an impact on portfolio selection within the usual mean-variance framework and found that the optimal portfolio weights are sensitive to internal control mechanisms, ownership concentration, managerial entrenchment and incentive compensation.

The other study from Maurer and Valiani (2007)[31] regarding the effectiveness of controlling the currency risk for international diversified mixed-asset portfolios found that European put-in-the-money options have the potential to substitute the optimally forward-hedged portfolios. Stepien and $\mathrm{Su}$ (2012)[32] examine the benefits of international equity portfolios. The results show that the equally-weighted global portfolio offers risk reduction opportunities for Polish investors and performance improvement potentials for US investors. In addition, US investors seem to fare better leaving their foreign investment unhedged, while Polish investors benefit from currency hedging.

\section{RESEARCH METHODOLOGY}

The objective of this study is to develop efficient frontier for portfolio investment that contributes to minimum risk for a given expected return. The modern portfolio theory indicates that the portfolio risk can be reducing by diversifying type of assets in investment.

The methodology implemented is this study is selection of assets, share price return calculation, normality statistical test, correlation evaluation and portfolio analysis. This study evaluates the effects of asset risk, return, correlation and diversification on probable investment portfolio returns.

\section{Data selection and share price calculation}

Firstly, this study selected two companies listed in main market of Kuala Lumpur Stock Exchange in Malaysia. The companies are Ajinomoto Malaysia Berhad and UMW Holdings Berhad. Ajinomoto Malaysia Berhad is focusing on market segment of consumer food mainly on seasoning. Meanwhile, UMW Holdings Berhad is focusing on market segment of automotive, equipment and manufacturing. Data of share price is collected from database of Thomson Reuters Datastream.

Next, the calculation of share price return is calculated using Equation (1). 
Where;

$R_{i, t}$ is return of share price in percentages,

$S P_{t}$ is share price in period $t$, and

$S P_{t+1}$ is share price in period $t+1$.

\section{Data selection and share price calculation}

The risk of each of asset is calculated using standard deviation formula as stated in Equation (2).

$$
S_{x}=\sqrt{\frac{\sum_{i=1}^{n}\left(x_{i}-\bar{x}\right)^{2}}{n-1}}
$$

Where;

$n$ is number of data points,

$x_{i}$ is each of data value, and

$\bar{x}$ is mean of variable $x$, as stated in Equation (3).

$$
\bar{x}=\frac{\sum_{i=1}^{n} x_{i}}{n}
$$

Correlation statistical mathematical derivation using Pearson product-moment correlation coefficient

Pearson's correlation coefficient is the covariance of the two variables divided by the product of their standard deviations. The correlation coefficient for population is represented by Equation (4).

$$
\rho_{X, Y}=\frac{\operatorname{cov}(X, Y)}{\sigma_{X} \sigma_{Y}}
$$

Where;

$\operatorname{cov}(X, Y)$ is covariance between variable $X$ and $Y$,

$\sigma_{X}$ is standard deviation of variable $X$, and

$\sigma_{Y}$ is standard deviation of variable $Y$.

Next, the formula for population correlation coefficient can be expressed using mean and expectation. The covariance between variable $\mathrm{X}$ and $\mathrm{Y}$ can be expressed as Equation (5).

$$
\operatorname{cov}(X, Y)=\mathrm{E}\left[\left(X-\mu_{X}\right)\left(Y-\mu_{Y}\right)\right]
$$

Therefore, Equation (4) can be re-arranged to become Equation (6).

$$
\rho_{X, Y}=\frac{E\left[\left(X-\mu_{X}\right)\left(Y-\mu_{Y}\right)\right]}{\sigma_{X} \sigma_{Y}} \ldots
$$

Where;

Where;

$\mu_{X}$ is mean of variable $X$,

$\mu_{Y}$ is mean of variable $Y$, and

$\mathrm{E}$ is expectation.

Next, the Pearson correlation coefficient can be rearranged using un-centered moments. The correlation coefficient is derived using below parameters. Mean of variables is described as follows:

$$
\mu_{X}=\mathrm{E}[X] \text {, and }
$$

$R_{i, t}=\frac{S P_{t+1}-S P_{t}}{S P_{t}} \times 100 \%$

$\mu_{Y}=\mathrm{E}[Y]$.

Variance of variables is described as follows:

$$
\begin{aligned}
\sigma_{X}^{2} & =\mathrm{E}\left[(X-\mathrm{E}[X])^{2}\right] \\
& =\mathrm{E}[(X-\mathrm{E}[X])(X-\mathrm{E}[X])] \\
& =\mathrm{E}\left[X^{2}-2 X \mathrm{E}[X]+(\mathrm{E}[X])^{2}\right] \\
& =\mathrm{E}\left[X^{2}\right]-2(\mathrm{E}[X])^{2}+(\mathrm{E}[X])^{2} \\
& =\mathrm{E}\left[X^{2}\right]-(\mathrm{E}[X])^{2} \\
\sigma_{Y}^{2} & =\mathrm{E}\left[(Y-\mathrm{E}[Y])^{2}\right] \\
& =\mathrm{E}[(Y-\mathrm{E}[Y])(Y-\mathrm{E}[Y])] \\
& =\mathrm{E}\left[Y^{2}-2 Y \mathrm{E}[Y]+(\mathrm{E}[Y])^{2}\right] \\
& =\mathrm{E}\left[Y^{2}\right]-2(\mathrm{E}[Y])^{2}+(\mathrm{E}[Y])^{2} \\
& =\mathrm{E}\left[Y^{2}\right]-(\mathrm{E}[Y])^{2}
\end{aligned}
$$

Covariance between variable $\mathrm{X}$ and $\mathrm{Y}$ is described as follows:

$$
\begin{aligned}
& \operatorname{cov}(X, Y) \\
& =\mathrm{E}\left[\left(X-\mu_{X}\right)\left(Y-\mu_{Y}\right)\right] \\
& =\mathrm{E}[(X-\mathrm{E}[X])(Y-\mathrm{E}[Y])] \\
& =\mathrm{E}[X Y-X \mathrm{E}[Y]-Y \mathrm{E}[X]+\mathrm{E}[X] \mathrm{E}[Y]] \\
& =\mathrm{E}[X Y]-\mathrm{E}[X \mathrm{E}[Y]]-\mathrm{E}[Y \mathrm{E}[X]]+\mathrm{E}[\mathrm{E}[X] \mathrm{E}[Y]] \\
& =\mathrm{E}[X Y]-\mathrm{E}[X] \mathrm{E}[Y]-\mathrm{E}[Y] \mathrm{E}[X]+\mathrm{E}[X] \mathrm{E}[Y] \\
& =\mathrm{E}[X Y]-\mathrm{E}[X] \mathrm{E}[Y]
\end{aligned}
$$

Therefore, Pearson correlation coefficient for population is re-arranged as Equation (7).

$$
\rho_{X, Y}=\frac{\mathrm{E}[X Y]-\mathrm{E}[X] \mathrm{E}[Y]}{\sqrt{\mathrm{E}\left[X^{2}\right]-[\mathrm{E}[X]]^{2}} \sqrt{\mathrm{E}\left[Y^{2}\right]-[\mathrm{E}[Y]]^{2}}}
$$

In this study, Pearson correlation is performed using sample from population. Therefore Equation (7) needs to recalculate using below procedure. Consider the sample is derived from two data sets. The first data set is $\left\{x_{1}, x_{2}, x_{3}, \ldots, x_{n}\right\}$ containing $n$ values. The second data set is $\left\{y_{1}, y_{2}, y_{3}, \ldots, y_{n}\right\}$. The sample Pearson correlation coefficient is described as Equation (8).

$$
r=\frac{\sum_{i=1}^{n}\left(x_{i}-\bar{x}\right)\left(y_{i}-\bar{y}\right)}{\sqrt{\sum_{i=1}^{n}\left(x_{i}-\bar{x}\right)^{2}} \sqrt{\sum_{i=1}^{n}\left(y_{i}-\bar{y}\right)^{2}}}
$$

Where;

$n$ is the sample size,

$x_{i}$ and $y_{i}$ are the individual sample point indexed with $i$ th observation, and 
$\bar{x}$ is sample mean for variable $x$ represented by Equation (9).

$$
\bar{x}=\frac{\sum_{i=1}^{n} x_{i}}{n}
$$

$\bar{y}$ is sample mean for variable $y$ represented by Equation (10).

$$
\bar{y}=\frac{\sum_{i=1}^{n} y_{i}}{n}
$$

The Equation (8) can be re-arranged using next procedure:

$$
\begin{gathered}
r=\frac{\sum_{i=1}^{n}\left(x_{i} y_{i}-x_{i} \bar{y}-\bar{x} y_{i}+\bar{x} \bar{y}\right)}{\sqrt{\sum_{i=1}^{n}\left(x_{i}-2 x_{i} \bar{x}+\bar{x}^{2}\right)} \sqrt{\sum_{i=1}^{n}\left(y_{i}-2 y_{i} \bar{y}+\bar{y}^{2}\right)}} \\
r=\frac{\sum_{i=1}^{n}\left(x_{i} y_{i}\right)+\sum_{i=1}^{n}\left(-x_{i} \bar{y}\right)+\sum_{i=1}^{n}\left(-\bar{x} y_{i}\right)+\sum_{i=1}^{n}(\bar{x} \bar{y})}{\sqrt{\sum_{i=1}^{n}\left(x_{i}-2 x_{i} \bar{x}+\bar{x}^{2}\right)}}
\end{gathered}
$$

The Pearson correlation coefficient after the derivation is shown in Equation (11).

$$
r=\frac{\sum_{i=1}^{n}\left(x_{i} y_{i}\right)-n \bar{x} \bar{y}}{\sqrt{\left(\sum_{i=1}^{n} x_{i}^{2}-n \bar{x}^{2}\right)} \sqrt{\left(\sum_{i=1}^{n} y_{i}^{2}-n \bar{y}^{2}\right)}} .
$$

Equation for Modern Portfolio Theory (MPT) in calculating expected return and expected risk of portfolio investment

Modern Portfolio Theory (MPT) is a theory of finance that attempts to maximize portfolio expected return for a given amount of risk, or minimize the risk for a given level of expected return (Ross, et al., 2015) [33].

Modern portfolio theory is also known as Markowitz portfolio theory. Markowitz provides tool for identifying the portfolio which give the highest return for a particular level of risk. Markowitz states total risk of the portfolio can be reduced by diversification. The risk can be reduced by selecting assets with low positive correlation or negative correlation.

There are five assumptions that underlying this theory. The assumptions are:

(a) Investors consider each investment alternatives as being presented by a probability distribution of expected returns of over some holding periods.

(b) Investors maximize one-period expected utility and their utility curve demonstrates diminishing marginal utility of wealth.

(c) Investors estimate the risk of the portfolio on the basis of the variability of expected returns.

(d) Investors' base decision solely on expected return and risk, therefore their utility curves based on function of expected return and expected standard deviation. (e) For a given level of risk, investors prefer higher returns to lower returns. Similarly, for a given level of expected returns, investors prefer less risk to more risk.

The modern portfolio theory is constructed by two main equations which are expected return and variance for a portfolio investment. The expected rate of return for portfolio is weighted average of expected returns on the securities in the portfolio, as shown in Equation (12).

$\mathrm{E}\left(r_{p}\right)=w_{A} \mathrm{E}\left(r_{A}\right)+w_{B} \mathrm{E}\left(r_{B}\right)$.

Where;

$\mathrm{E}\left(r_{p}\right)$ is estimation for rate of return of portfolio,

$\mathrm{E}\left(r_{\mathrm{A}}\right)$ is estimation for rate of return of asset $\mathrm{A}$,

$w_{A}$ is investment weightage for asset $\mathrm{A}$,

$\mathrm{E}\left(r_{B}\right)$ is estimation for rate of return of asset $\mathrm{A}$,

$w_{B}$ is investment weightage for asset $\mathrm{B}$.

The variance of the rate of return for two risky assets portfolio is represented by Equation (13).

$$
\sigma_{p}^{2}=\left(w_{A} \sigma_{A}\right)^{2}+\left(w_{B} \sigma_{B}\right)^{2}+2\left(w_{A} \sigma_{A}\right)\left(w_{B} \sigma_{B}\right) \rho_{A B} \ldots
$$

Where;

$\sigma_{p}$ is standard deviation for portfolio return,

$\sigma_{A}$ is standard deviation for stock A return,

$\sigma_{B}$ is standard deviation for stock B return, and

$\rho_{A B}$ is Pearson correlation coefficient between the return of stock A and stock B.

\section{RESULTS AND DISCUSSIONS}

The objective of this study is to develop efficient frontier to find optimal combination weightage of investment for two stocks. The efficient frontier has potential higher return with lower degree of risk. Therefore, this section describes regarding data selection, data normality distribution evaluation, correlation analysis and development of efficient frontier for portfolio investment.

Data selection and statistical analysis for Ajinomoto Malaysia Berhad

The first company of stock price that selected in this study is Ajinomoto Malaysia Berhad. Ajinomoto Malaysia Berhad is listed in main market of Kuala Lumpur Stock Exchange in Malaysia. Ajinomoto Malaysia Berhad is a food and seasoning manufacturer.

Data for this study is collected from Thomson Reuters Datastream. Share price data is collected daily from June 2013 until December 2016. Next, this study calculated monthly share price using averaging method. Figure 1 shows the dynamic behavior of monthly share price for Ajinomoto Malaysia Berhad from June 2013 until December 2016. The value of share price in first observation (June 2013) is MYR 4.403. Meanwhile, the value of share on last observation (December 2016) is MYR 13.84. The maximum value of monthly share price is MYR 14.55 on August 2016. 


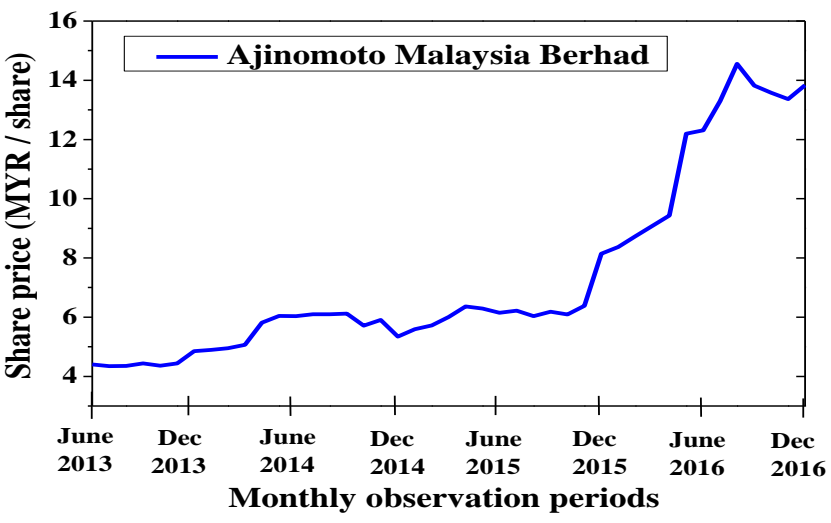

Figure 1: Dynamic behavior of share price for Ajinomoto Malaysia Berhad

Next, this study calculated return of share price using data of June and December from each year. Figure 2 shows the return of share price for Ajinomoto Malaysia Berhad. The minimum value of return is $-11.43 \%$ in December 2014 . Meanwhile, the maximum value of return is $51.16 \%$ in June 2016.

This study performed normality test to evaluate data distribution of share price return for Ajinomoto Malaysia Berhad. There are two method performed to evaluate the normal distribution of data. The first method is using graphical method namely normal probability plot. Figure 3 shows normal probability plot of share price return for Ajinomoto Malaysia Berhad. The red line is represented reference line for normal distribution data. The blue dot represented data of share price return. The graphical test concluded that the distribution of data follows normal distribution because all the data points are close to normal probability reference line.

Next, this study validated the findings using numerical statistical test. The number of observations in this analysis is seven data points. Therefore, the appropriate numerical normality test is Shapiro-Wilk. Table 1 shows the ShapiroWilk normality test for share price return of Ajinomoto Malaysia Berhad. The significant value is 0.934 which larger than 0.05 . This study failed to reject null hypotheses. Therefore, data distribution of share price return follows normal distribution. The mean is $19.17 \%$ and standard deviation is $19.62 \%$.

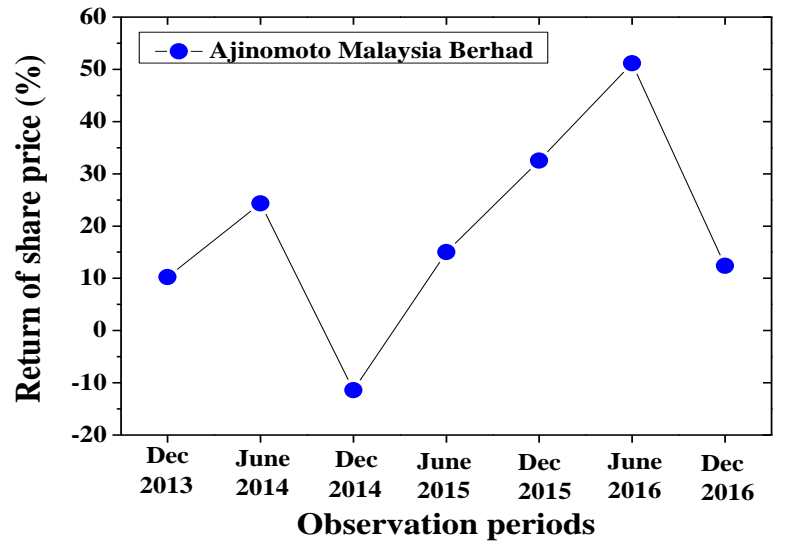

Figure 2: Return of share price for Ajinomoto Malaysia Berhad

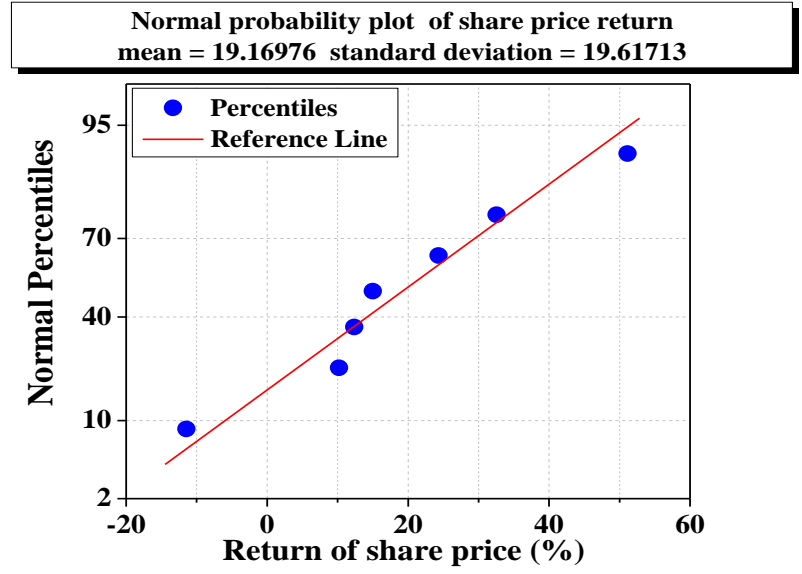

Figure 3: Normal probability plot of share price return for Ajinomoto Malaysia Berhad

Table 1: Test of normal data distribution for share price return of Ajinomoto Malaysia Berhad

\begin{tabular}{|c|c|c|}
\hline \multicolumn{2}{|c|}{ Shapiro-Wilk normality test } \\
\hline $\begin{array}{c}\text { Statistic } \\
\text { value }\end{array}$ & $\begin{array}{c}\text { Degree of } \\
\text { freedom }\end{array}$ & $\begin{array}{c}\text { Significant } \\
\text { value }\end{array}$ \\
\hline 0.975 & 7 & 0.934 \\
\hline
\end{tabular}

Data selection and statistical analysis for UMW Holdings Berhad

The second stock price that selected in this study is UMW Holdings Berhad. UMW Holdings Berhad is listed in main market of Kuala Lumpur Stock Exchange in Malaysia. UMW Holdings Berhad is a leading industrial enterprise with diverse and global interests in the automotive, equipment, manufacturing and engineering industries.

Data for this study is collected from Thomson Reuters Datastream. Share price data is collected daily from June 2013 until December 2016. Next, this study calculated monthly share price using averaging method. Figure 4 shows the dynamic behavior of monthly share price for UMW Holdings Berhad from June 2013 until December 2016.The value of share price in first observation (June 2013) is MYR 13.40. Meanwhile, the value of share on last observation (December 2016) is MYR 4.47.

Next, this study calculating return of share price using data of June and December from each year. Figure 5 shows the return of share price for UMW Holdings Berhad. The minimum value of return is $-30.142 \%$ in June 2016 . Meanwhile, the maximum value of return is $-0.485 \%$ in December 2014

This study performed normality test to evaluate data distribution of share price return for UMW Holdings Berhad. There are two method performed to evaluate the normal distribution of data. The first method is using graphical method namely normal probability plot. Figure 6 shows normal probability plot of share price return for UMW Holdings Berhad. The red line is represented reference line for normal distribution data. The red dot represented data of share price return. From the normal percentiles graph, this study concluded that the data appears 
to be normally distributed as it follows the diagonal line closely and does not appear to have a non-linear pattern.

Next, this study validated the findings using numerical statistical test. The number of observations in this analysis is seven data points. Therefore, the appropriate numerical normality test is Shapiro-Wilk. The null-hypothesis of this test is that the population is normally distributed.

Table 2 shows the Shapiro-Wilk normality test for share price return of UMW Holdings Berhad. The chosen alpha level is 0.05 . Alpha level is a level of type I error which is error level supporting the alternate hypothesis when the null hypothesis is true. The significant value is 0.934 which larger than 0.05. This study failed to reject null hypotheses. Therefore, data distribution of share price return follows normal distribution. The mean is $-13.92 \%$ and standard deviation is $10.7 \%$.

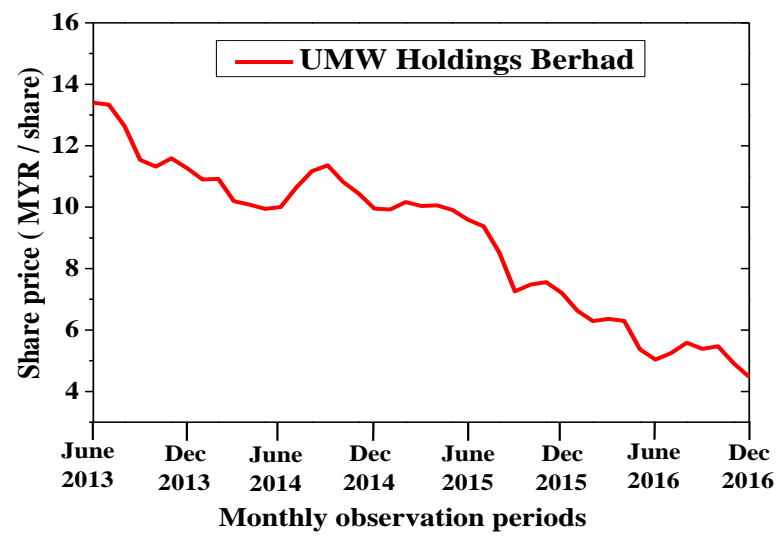

Figure 4: Dynamic behavior of share price for UMW Holdings Berhad

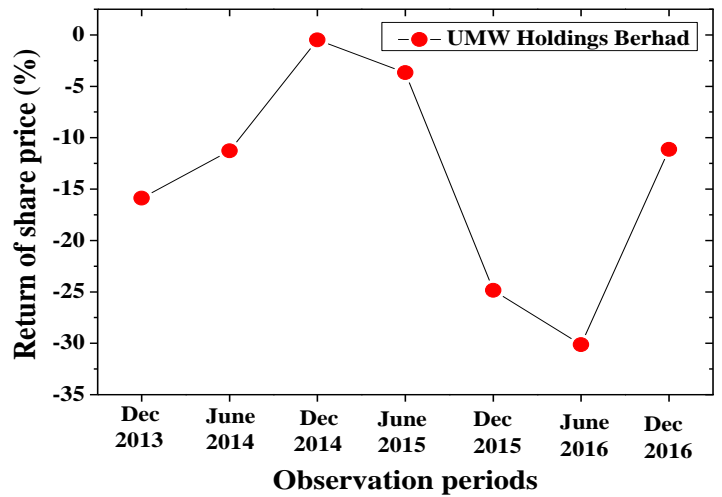

Figure 5: Return of share price for UMW Holdings Berhad

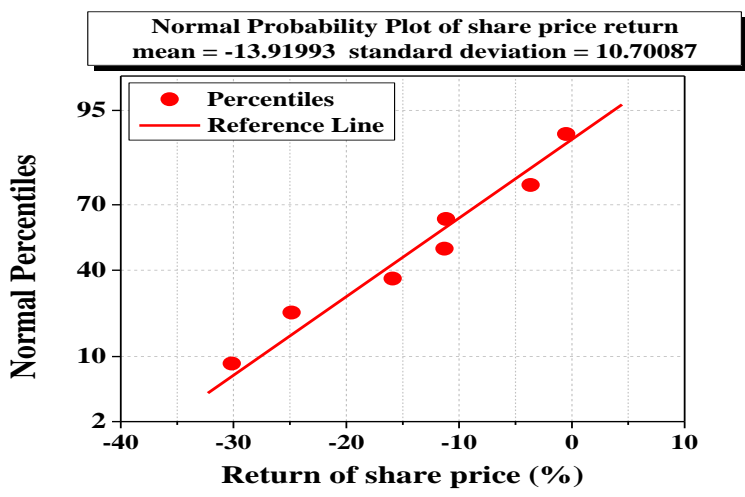

Figure 6: Normal probability plot of share price return for UMW Holdings Berhad
Table 2: Test of normal data distribution for share price return of UMW Holdings Berhad

\begin{tabular}{|c|c|c|}
\hline \multicolumn{2}{|c|}{ Shapiro-Wilk normality test } \\
\hline $\begin{array}{c}\text { Statistic } \\
\text { value }\end{array}$ & $\begin{array}{c}\text { Degree } \\
\text { freedom }\end{array}$ & $\begin{array}{c}\text { Significant } \\
\text { value }\end{array}$ \\
\hline 0.952 & 7 & 0.746 \\
\hline
\end{tabular}

Statistical correlation test between share price return of Ajinomoto Malaysia Berhad and UMW Holdings Berhad

This section describes the correlation test of share price return between two companies namely Ajinomoto Malaysia Berhad and UMW Holdings Berhad. This section evaluates the data distribution using graphical and numerical statistical test approach.

The first method is using graphical method namely correlation plot graph. Figure 7 shows correlation graph for share price return between UMW Holdings Berhad and Ajinomoto Malaysia Berhad. The graph shows there is a negative correlation pattern between share price return.

The second method is numerical method namely Pearson correlation test. Null hypothesis of Pearson correlation test is there is no relationship between the variables. The value of chosen alpha (Type- 1 error) is 0.05 . The significant value is 0.009 less than 0.05 . Therefore, this study rejected null hypothesis. The Pearson correlation test stated that there is significant correlation between share price return of UMW Holdings Berhad and Ajinomoto Malaysia Berhad.

The Pearson correlation analysis also indicates correlation value is -0.879 . This finding concludes there is significant and strong negative correlation between share price return of UMW Holdings Berhad and Ajinomoto Malaysia Berhad.

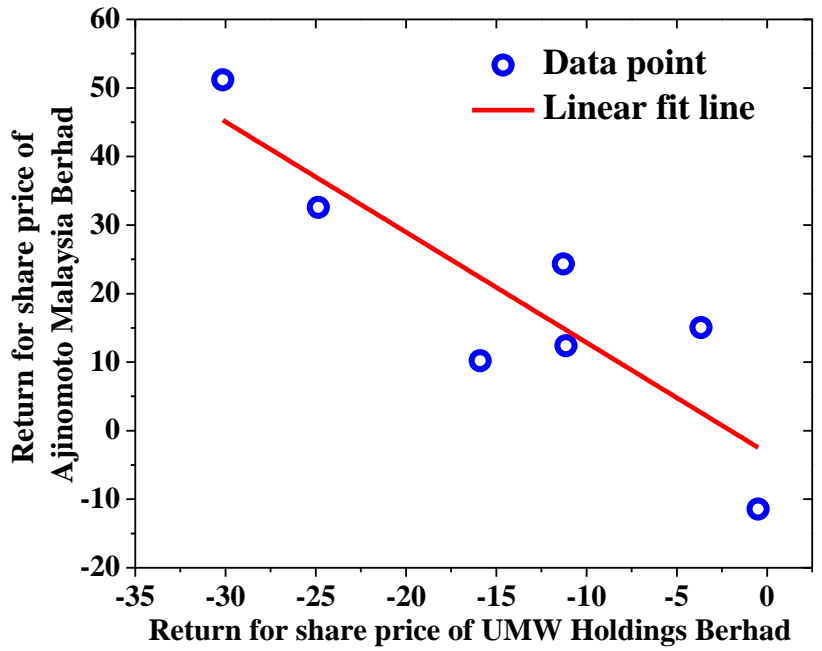

Figure 7: Correlation graph for share price return between UMW Holdings Berhad and Ajinomoto Malaysia Berhad 
Table 3: Test of Pearson correlation for share price return between UMW Holdings Berhad and Ajinomoto Malaysia Berhad

\begin{tabular}{|c|l|}
\hline \multicolumn{2}{|c|}{ Pearson correlation test } \\
\hline Correlation value & -0.879 \\
\hline $\begin{array}{c}\text { Significant value (2-tailed } \\
\text { normal distribution) }\end{array}$ & 0.009 \\
\hline Number of observations & 7 \\
\hline
\end{tabular}

Modern portfolio theory calculation for relationship of portfolio return with portfolio risk

This section analyzed portfolio risk and portfolio return. Analysis started with setting the weightage for Ajinomoto share price is $100 \%$ and zero percentage in UMW share price. The weightage of Ajinomoto share price reduced until achieve zero percentage. In the same time, the investment weightage for UMW share price is increased from zero percentage until achieve $100 \%$. This study calculated portfolio risk and portfolio return for each of investment weightage combination between share price Ajinomoto Malaysia Berhad and UMW Holdings Berhad. Figure 8 shows portfolio risk and portfolio return for combination of two stock prices.

Next, this study developed efficient frontier analysis. Figure 9 shows efficient frontier for portfolio investment using two share prices in Kuala Lumpur stock exchange. Result indicates the efficient frontier for investment is started with $42.5 \%$ investment in Ajinomoto and 57.5\% investment in UMW. The expected portfolio return using this investment combination is 0.14 percentages. Meanwhile, the highest expected return on efficient frontier is 19.17 percentages. The investment combination for maximum return is $100 \%$ in Ajinomoto share price.

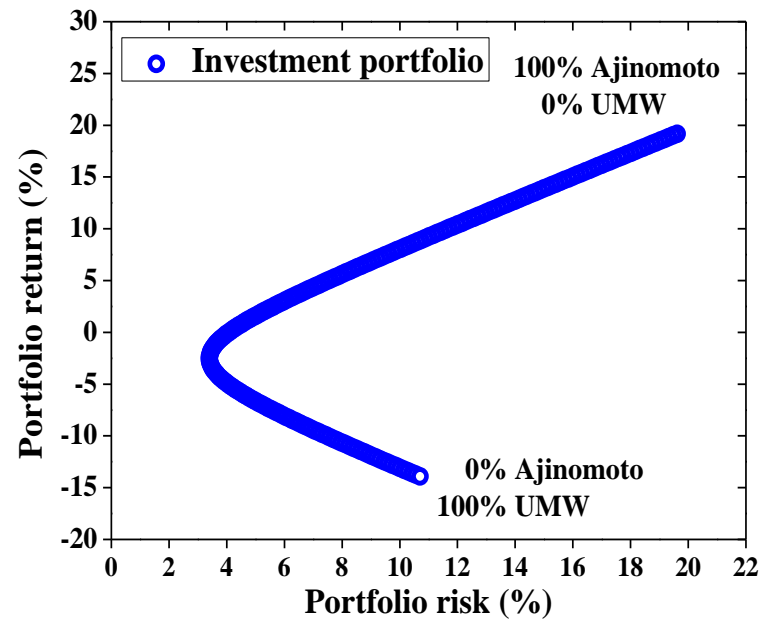

Figure 8: Portfolio risk and portfolio return analysis

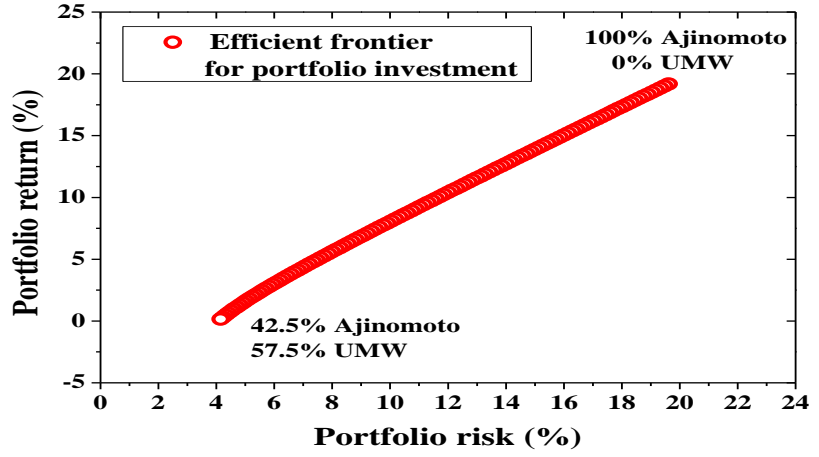

Figure 9: Efficient frontier for portfolio investment

\section{CONCLUSIONS}

The objective of this study is to develop efficient frontier for portfolio investment that can produce greatest return with lowest degree of risk. Modern Portfolio Theory (MPT) is a theory of finance that attempts to maximize portfolio expected return for a given amount of risk. In other word, Modern Portfolio Theory is to minimize the risk for a given level of expected return.

The main findings of this study are:

(a) This study selected two share prices namely Ajinomoto Malaysia Berhad and UMW Holdings Berhad. Both of the companies listed in main market of Kuala Lumpur Stock Exchange in Malaysia.

(b) This study calculating return of share price using data of June and December from each year. For share price return of Ajinomoto Malaysia Berhad, minimum value of return is $-11.43 \%$ in December 2014. Meanwhile, the maximum value of return is $51.16 \%$ in June 2016. The mean is $19.17 \%$ and standard deviation is $19.62 \%$.

(c) From UMW share price return, minimum value of return is $-30.142 \%$ in June 2016. Meanwhile, the maximum value of share price return is $-0.485 \%$ in December 2014 . The mean is $-13.92 \%$ and standard deviation is $10.7 \%$.

(d) The Pearson correlation analysis shows correlation value is -0.879 . This finding concludes there is significant and strong negative correlation between share price return of UMW Holdings Berhad and Ajinomoto Malaysia Berhad.

(e) Next, this study developed efficient frontier analysis. Result indicates the efficient frontier for investment is started with $42.5 \%$ investment in Ajinomoto and $57.5 \%$ investment in UMW. The expected portfolio return using this investment combination is 0.14 percentages. Meanwhile, the highest expected return on efficient frontier is 19.17 percentages. The investment combination for maximum return is $100 \%$ in Ajinomoto share price.

The implication of this study is it will help investors to develop better decision about their portfolio investment with lower risk for a target of expected return. It is depending on the investors whether to maximize the return or minimize the portfolio risk. The main purpose of this study is with diversifying the weightage of investment in different shares, investor can have lower risk of portfolio with a given level 
of expected return.

This study can be extending to develop investment portfolio with more diversifying asset including stocks, bonds and other financial instruments. The diversification also can be extending to different market segments and different financial instruments in different stock exchange on other countries.

This study also can be further extending to discuss the variables that contribute to significant stock prices behavior in Malaysia Stock Exchange. This analysis will help investors to understand Malaysia Stock Market in more robust and reliable.

\section{REFERENCES}

1. Markowitz, H. (1952). Portfolio selection. Journal of Finance, 7(1), 77-91.

2. Fabozzi, F.J., Gupta, F. \& Markowitz, H.M. (2002). The legacy of modern portfolio theory. The Journal of Investing, 7-22.

3. Abu Bakar, N. and Rosbi, S. (2018). Evaluation of Risk Reduction for Portfolio in Islamic Investment Using Modern Portfolio Theory. International Journal of Advanced Engineering Research and Science, 5(11), $27-$ 34.

4. Abu Bakar, N. and Rosbi, S. (2018). Diversification Diagnostics for Portfolio Investment Using Combination of Cryptocurrency and Stock Price. International Journal of Advanced Research, 6(10), 1528-1539.

5. Bahlous, M. \& Mohd. Yusof, R. (2014). International diversification among Islamic investments: is there any benefit. Managerial Finance, 40(6), 613-633

6. Bartkus, J.R. \& Kabir Hassan, M. (2009). Specialization versus diversification in venture capital investing. Journal of Financial Regulation and Compliance, 17(2), 134-145.

7. Securities Commission of Malaysia (2018). Available at: https://www.sc.com.my/wp-

content/uploads/eng/html/icm/sas/sc_syariahcompliant_1 80525a.pdf

8. Kazan, H. \& Uludag, K. (2014). Credit Portfolio Selection According to Sectors in Risky Environments: Markowitz Practice. Asian Economic and Financial Review, 4(9), 1208-1219.

9. Bin, R.L.L. and Yuan, C.J. (2016). Portfolio Diversification Strategy in the Malaysian Stock Market. Capital Markets Review, 24(1), 38-67.

10. Abu Bakar, N. and Rosbi, S. (2018). Efficient Frontier Analysis for Portfolio Investment in Malaysia Stock Market. Science International (Lahore), 30(5), 723-729.

11. Zainudin, R., Mahdzan, N.S. \& Yet, C.H. (2018). Dividend policy and stock price volatility of industrial products firms in Malaysia. International Journal of Emerging Markets, 13(1), 203-217

12. Fauzi, H. \& Musallam, S.R.M. (2015). Corporate ownership and company performance: a study of Malaysian listed companies. Social Responsibility Journal, 11(3), 439-448.

13. Ahmad-Zaluki,N.A. (2012). The pre and post-IPOs gender composition of board of directors in Malaysia. Gender in Management: An International Journal, 27(7), 449-462.

14. Lim, K.P. (2008). Sectoral efficiency of the Malaysian stock market and the impact of the Asian financial crisis. Studies in Economics and Finance, 25(3), 196-208.

15. Mayes, D. \& Alqahtani, F. (2015). Underpricing of IPOs in Saudi Arabia and Sharia compliance. Journal of Islamic Accounting and Business Research, 6(2), 189207.
16. Davis, M.H.A. \& Norman, A.R. (1990). Portfolio selection with transaction costs. Mathematics of Operations Research, 15(4), 676-713.

17. Mansini, R. \& Speranza, M.G. (1999). Heuristic algorithms for the portfolio selection problem with minimum transaction lots. European Journal of Operational Research, 144: 219-233.

18. Sing, T.F. \& Patel, K., (2001). Effects of portfolio diversification on property investment company stock prices: 1983-1994. Journal of Property Investment \& Finance, 19(4): 390-411.

19. Maurer, R. \& Valiani, S., (2007). Hedging the exchange rate risk in international portfolio diversification: Currency forwards versus currency options. Managerial Finance, 33(9), 667-692

20. Benjelloun, H. \&Abdulkader M.A. Abdullah, (2009). Index funds and diversification in Saudi Arabia. International Journal of Islamic and Middle Eastern Finance and Management, 2(3), 201-212.

21. Nartea, G. \& Eves, C. (2010). Role of farm real estate in a globally diversified asset portfolio. Journal of Property Investment \& Finance, 28(3), 198-220.

22. Giannotti, C., Mattarocci, G. \& Spinelli, L. (2011). The role of portfolio diversification in the hotel industry: Evidence from the Italian market. EuroMed Journal of Business, 6(1), 24-45.

23. Chen, L. \& Pan, H. (2013). A dynamic portfolio theory model based on minimum semi-absolute deviations criterion with an application in the Chinese stock markets, China Finance Review International, 3(3), 284 300.

24. Lee, S. \& Stevenson, S. (2005). Real estate portfolio construction and estimation risk. Journal of Property Investment \& Finance, 23(3), 234-253.

25. Puopolo, G.W. (2017). Portfolio selection with transaction costs and default risk. Managerial Finance, 43(2): 231-241

26. Champagne, C., Karoui, A. \& Patel, S. (2018). Portfolio turnover activity and mutual fund performance. Managerial Finance, 44(3): 326-356.

27. Azizan, N.A. \& Sorooshian, S. (2014). Stock Market performance and modern portfolio theory: Case on Malaysian stock market and Asian Indices. WSEAS Transactions on Business and Economics, 11: 303-313.

28. Ou, J. (2005). Theory of portfolio and risk based on incremental entropy. The Journal of Risk Finance, 6(1): 31-39.

29. Giannotti, C., Mattarocci, G. \& Spinelli, L. (2011). The role of portfolio diversification in the hotel industry: Evidence from the Italian market. EuroMed Journal of Business, 6(1): 24-45.

30. Lassoued, N. \& Elmir, A. (2012). Portfolio selection: does corporate governance matter? Corporate Governance: The International Journal of Business in Society, 12(5): 701-713.

31. Maurer, R. \& Valiani,S. (2007). Hedging the exchange rate risk in international portfolio diversification: Currency forwards versus currency options. Managerial Finance, 33(9): 667-692.

32. Stepien, E. \& Su, Y. (2012). International portfolios and currency hedging: viewpoint of Polish investors. Managerial Finance, 38(7): 660-677.

33. Ross, S. A., Westerfield, R.W., Jaffe, J.F. \& Jordan, B.D., (2015) Corporate Finance: Core Principles and Applications, New York, NY, McGraw-Hill Education. 